\title{
ICTS USAGE AMONG RURAL COMMUNITIES IN THE INFORMATION AGE: A CASE STUDY OF SMALL SCALE FARMERS IN EASTERN CAPE PROVINCE SOUTH AFRICA
}

\author{
Agyei Fosu and Darelle van Greunen \\ Nelson Mandela University \\ P O Box 77000, Nelson Mandela University, Port Elizabeth, 6031, South Africa
}

\begin{abstract}
There is a mismatch between research output and farmers' ICT practices. In this case study in the former Transkei and Ciskei Homelands, 48 small-scale farmers were approached to understand the factors that impede ICTs use to access agricultural information. The farmers were found to use and see the usefulness of ICTs basically in terms of social interactions and the most frequent used ICTs by respondents are mobile phone (100\%) followed by radio (58.3\%), Television (18.8\%), Internet (10.4\%) and news paper (6.3\%). There is a need to do an in-depth research about e-skills of the farmers and other factors that may be causing hindrance to the usage of other recent advances of Internet and ICTs for seeking information.
\end{abstract}

\section{KEYWORDS}

ICTs, Information Age, Development, Small Scale Farmers

\section{INTRODUCTION}

Development literature is fraught with various perspectives on how to improve living conditions in rural areas. Central to all these perspectives put forward for rural development is the assertion of Chambers and Conway, (1991) that explains the process of rural development to involves a participatory set of activities that must involves local people, the natural environment, outside development practitioners, and other stakeholders such as developmental agencies. In the course of embarking on these set of activities, different forms of knowledge are generated of which access to these knowledge as well as its implementation becomes critical to attaining development for that area. Knowledge and access been crucial for any development and also can make rural development process achievable has been highlighted by Wong, (2010); Bruckmeier and Tovey, (2008). Thus, the achievability of the rural development process and its sustainability relies on availability of information to the rural communities and their ability to access and use the information for improvement of their livelihood is imperative towards the sustainability of the rural development process in the information age (Ali et al., 2015). Information and Communication Technologies (ICTs) can play a significant role in rural sustainability development process by serving as a platform to capture, convert, store and share the knowledge generated during the rural development process activities in the form of Internet and Intranet web portals, digital libraries, blogs, as well as mobile and smart phones, CDs and DVDs, TV and radio broadcasts. If ICTs are appropriately deployed and effectively utilized it can become a powerful tool to address some of the challenges and also can aid the uplifting of the livelihoods of poor people in rural areas in the information age.

Agriculture as an economy sector worldwide in the information age is not spared from the crucial needs of information to increase production, improve marketing and distribution strategies (Oladele, 2006). With information, farmers can be empowered with best farming practices, sources of financial assistances and available market places for their produce. Agriculture is an important sector in most developing countries' economy as majority of their population lives in rural areas and earns their livelihood by agriculture in the form of small scale farming is well documented. With the major challenges such as water shortages, 
declining soil fertility, effects of climate change, etc., facing small scale farmers day to day, there is continual urgent need for new approaches and technical innovations for small scale farmers to cope with these challenges and to enhance the livelihoods of the rural population. This is where the availability and use of ICTs can make a significant contribution by serving as a medium or platform to deliver useful agricultural information to small scale farmers about crop care, animal husbandry, fertilizer applications, feedstocks, market prices to increase productivity and efficiency as well as sustainability of small scale farming.

\subsection{Problem Statement and Background of the Study}

The role of ICTs to enhance food security and support rural livelihoods is recognized and was officially endorsed at the World Summit on the Information Society (WSIS) 2005. One of the thoughts behind the use of ICTs that includes radio, TV, mobile phone and Internet in the agricultural sector was to applied these tools to narrow the gap between researchers and farmers by providing channels to convey information between researchers, extension agents and farmers (Nyirenda-Jere, 2010; Musa et al., 2013). However, it has been demonstrated that the linkages between researchers, extension agents and farmers is not effective and that there is a mismatch between research output and on farm practices (Simumba and Koopman, 2011, Musa et al., 2013). Even though Internet access and ICTs devices are becoming more common in South Africa (World Bank, 2008; Goldstuck, 2012), the use of them to enhance farming activities are limited. In view of this, it is important to carry out research on ICTs usage especially among rural farmers to understand the factors that impede its use to access agricultural information.

The research question for the study is: How can ICTs usage to seek or access agricultural information among small scale farmers support sustainable rural development in the information age?

Thus, we hypothesize that the use of ICTs among small scale farmers to access agricultural information can make sustainable rural development goal achievable.

One is not far from the truth to assert that for rural communities to play a meaningful role in developing countries economy in the information age, access to information is paramount. Hence, it is also critical to check information needs; information practices of the indigenous people in this context the small scale farmers prior to understanding the ICTs usage among them. Maepa (2000) argues that the concept of information needs does not only presuppose the lack of information, but it also means linking the need with the use of that information to solve a problem. Suggesting also that once a person has identified the information needs, then the person is in a better position not only to seek the information but also be able to determine where and means or medium to use to seek the information. The information needs assessment in this study will seek to answer the following questions which are also the specific objectives of the study is to:

1. Specify the information needs of the small scale farmers.

2. Describe conditions for information sharing among the small scale farmers as a community.

3. Specify the type and rate of usage of ICTs to access/seek information needs.

This study examines the case of black small scale farmers in the former Transkei and Ciskei Homelands in the Eastern Cape Province South Africa. The region is typically an area of widespread large rural population with agricultural based rural economy and deep poverty where illiteracy, unemployment and poor access to basic and social services continue to be endemic.

\subsection{Research Methodology}

The researchers designed a survey questionnaire and purposeful approached a total of 48 black small scale farmers in animal products and field crops from Peddie, Fort Beautfort, Idutywa, Ngqamakhwe, Keiskammahoek, Adelaide, Middledrift to gather quantitative data on their information needs, patterns of seeking information, type and rate of ICTs usage to access their information needs.

According to Bless et al., (2007) quantitative research methods enable a researcher to obtain relevant information from the sample group through a questionnaire with closed and open-ended questions which can be analyzed using descriptive and inferential statistics. The data were analyzed using MS Excel spreadsheet database for conversion into percentages for the descriptive statistics and thematic analysis was used for the 
open-ended question. The approach was that the researchers first visited the selected towns to identify the farmers, and then arranged a suitable time to meet them individual to administer and assist the farmers to answer the questionnaire. This process helped to overcome misunderstanding and misinterpretation of words or questions on the questionnaire.

\subsection{Literature Review}

Whilst the limitation of industrial resources, infrastructure in rural areas remains a challenge, but the rapid growth of ICTs and its gadgets have created opportunities for rural communities especially those in developing countries to participate in the21st century global digital and knowledge-based economy (normally called the information age) without the need to experience an industrial shift. For instance, the use of ICTs such as Internet, mobile phone in rural communities can help such areas overcome the physical barrier to access and participate in the global knowledge-based economy activities such as e-commerce, e-health and ecotourism.

There is ample empirical evidence in literature on key factors that influence ICTs usage and adoption among rural communities in Africa and other developing countries across the globe (James, 2010; Jacobs and Herselman, 2006; Meyer, 2003; Okon, 2015; Ramirez, 2001). Findings such as physical access; costs; lack of awareness of the benefits of ICTs; lack of skills; attitudinal barriers; literacy; content, gender and age, etc., have been identified by researchers such as Okon, (2015); Chatterjee et al., (2002); Musa et al., (2005); Cullen, (2001); Rao, (2003); as key factors that prevent rural people globally from reaping the benefits of ICTs and serves as barriers to using technology. In the case of small scale farmers in Africa, similar findings have been echoed in the findings of most studies. The study conducted by Musa et al., (2013) among farmers in Sudan's Gerzira State identified low education levels, low income, cultural inertia, inadequate ICTs skills among researchers and farmers, and the scarcity of relevant content in local languages as hurdles to adoption and use of ICT. Chavula (2013) in his study the role of ICTs in agricultural production in Africa used the 2000-2011 panel data for 34 Africa countries to assess if at all the proliferation of ICTs on the African continent has had any significant impact on agricultural production, found that ICTs play a significant role in enhancing agricultural production. Job et al., (2013) identified with regards to usage of ICTs by small scale farmers in Niger State, Nigeria, language barrier, poverty and illiteracy as challenges. According to the study of Anyan et al., (2018) to investigate into barriers that hinders the effective use of ICTs in farming by small scale farmers in Asuogyaman District in Ghana, found three main barriers namely attitudinal, accessibility and technical skills. Similar findings were identified by the study of Muriithi et al., (2009).

Various researchers writing on small scale farmers in Africa access and utilizing ICTs to increase productivity highlight the following. The study of Kituyi-Kwake et al., (2008) conducted on Kenya rural women farmers to analyze access and ICTs usage among them found that cost of the ICTs services, time, the far away of the ICTs services, computer illiteracy, poor roads and cultural taboos to be some of the constraints to ICTs adoption among the women. Cultural factors in the setting of cultural beliefs, legal frameworks and politics were identified in the study of a cross-tabulation between adoption of ICTs and cultural factors conducted by Musa et al., (2013). Chilimo (2008) reported that most of the small scale farmers who participated in the study of the four rural districts in Tanzania main access to ICTs are radio and mobile cell phones.

\section{DATA PRESENTATION AND DISCUSSION}

We are in the information age that is the call made by authors such as Castells, (2000); Hughes, (1991) and Friedman (2006) and they further sound the alarm that it is the age where information generation, processing and transformation are critical to societal functioning, change and development as well as it is also the age where ICTs enable the widespread expansion of vital information and networking for development throughout the societal structure. ICTs application in agriculture has become a critical tool due to its potential in improving agricultural productivity by serving as a platform to access vital agricultural information.

As highlighted early, in the information age, without information and the use of ICTs increasing productivity, efficiency and sustainability becomes a tall order. Thus, increasing productivity, efficiency and sustainability among rural small scale farmers certainly requires access and usage of ICTs. The key findings of the present study are presented below: 


\subsection{Demographic Information of Participants}

Studies have revealed that age, gender and educational levels do have influence when it comes to technology adoption and usage (Venkatesh et al., 2003). The age, gender and educational background of respondents are shown in Table 1 below.

Table 1. Demographic information of participants

\begin{tabular}{|l|l|l|}
\hline Age & Frequency & Percentage \\
\hline $25-30$ & 3 & 6.3 \\
\hline $31-36$ & 2 & 4.2 \\
\hline $37-42$ & 3 & 6.3 \\
\hline $43-48$ & 7 & 14.6 \\
\hline $49-54$ & 9 & 18.8 \\
\hline $55-60$ & 13 & 27.1 \\
\hline Above 61 & 11 & 22.9 \\
\hline \multicolumn{2}{|l|}{ Gender of respondents } \\
\hline Male & 44 & 91.7 \\
\hline Female & 4 & 8.3 \\
\hline \multicolumn{2}{|l|}{ Educational background of participants } \\
\hline No formal education & 23 & 47.9 \\
\hline Primary education & 6 & 12.5 \\
\hline Secondary education & 10 & 20.8 \\
\hline Post -secondary education & 9 & 18.8 \\
\hline
\end{tabular}

The findings from Table 1 shows that majority of respondents who took part in this study were aged between $55-60$ years $(27.1 \%)$ followed by those above 61 years $(22.9 \%)$. Approximately $18.8 \%$ were aged between $49-54$ years, $14.6 \%$ were aged between $43-48$ years, $6.3 \%$ were aged between $25-30$ years and $37-42$ years and the least percentage were aged $31-36$ years $(4.2 \%)$. The low number of young people in the study depicts that the youth are not been attracted to take up farming as a career. The findings also showed that there were more males $(91.7 \%)$ than females $(8.3 \%)$. This could probably be attributed to the fact that most household have males as breadwinners.

\subsection{Information needs and Habitual Source}

As asserted by Harris and Dewdney (1994) that people tend to follow the habitual patterns in seeking information, in exploring the information needs of respondents the habitual source of information seeking of the respondents were also explored in an open-end question on the questionnaire and the results are shown in Table 2 in common themes with frequencies and percentages below:

Table 2. Information needs and habitual source

\begin{tabular}{|c|c|c|c|}
\hline Information needs & Habitual source & Frequency & Percentage \\
\hline $\begin{array}{l}\text { Market prices for farm } \\
\text { produce }\end{array}$ & $\begin{array}{l}\text { 1)True relations (such as } \\
\text { family, friends and other } \\
\text { farmers) } \\
\text { 2)True social } \\
\text { gathering(such as church, } \\
\text { drinking bar) } \\
\text { 3) local market (such as } \\
\text { grocery shops ) } \\
\text { 4) True ICTs (such as } \\
\text { Radio, TV, Internet and } \\
\text { Newspaper) }\end{array}$ & $\begin{array}{l}\text { 1) } 42 \text { respondents } \\
\text { 2) } 5 \text { respondents } \\
\text { 3) } 33 \text { respondents } \\
\text { 4) } 7 \text { respondents }\end{array}$ & $\begin{array}{l}\text { 1) } 87.5 \\
\text { 2) } 10.4 \\
\text { 3) } 68.8 \\
\text { 4) } 14.6\end{array}$ \\
\hline
\end{tabular}




\begin{tabular}{|c|c|c|c|}
\hline $\begin{array}{l}\text { Prices for agricultural } \\
\text { products (such as } \\
\text { fertilizers, seeds, etc) }\end{array}$ & $\begin{array}{l}\text { 1)True relations } \\
\text { especially fellow farmers } \\
\text { 2) True local markets } \\
\text { 3) True agricultural } \\
\text { offices and officers }\end{array}$ & $\begin{array}{l}\text { 1)42 respondents } \\
\text { 2)30 respondents } \\
\text { 3) } 15 \text { respondents }\end{array}$ & $\begin{array}{l}\text { 1) } 87.5 \\
\text { 2) } 62.5 \\
\text { 3) } 31.3\end{array}$ \\
\hline $\begin{array}{l}\text { Farming practices (such } \\
\text { as pests and disease } \\
\text { control, fertilizer } \\
\text { application, animal care) }\end{array}$ & $\begin{array}{l}\text { 1)True relations } \\
\text { especially fellow farmers } \\
\text { 2)True ICTs especially } \\
\text { local radio programs on } \\
\text { agriculture } \\
\text { 3)True agricultural } \\
\text { officers and offices }\end{array}$ & $\begin{array}{l}\text { 1)45 respondents } \\
\text { 2)13 respondents } \\
\text { 3)36 respondents }\end{array}$ & $\begin{array}{l}\text { 1) } 93.8 \\
\text { 2) } 27.1 \\
\text { 3) } 75\end{array}$ \\
\hline $\begin{array}{l}\text { Government projects and } \\
\text { services (such as } \\
\text { financial aid, health, } \\
\text { home affairs) }\end{array}$ & $\begin{array}{l}\text { 1)True relations } \\
\text { 2)True Community } \\
\text { leaders } \\
\text { 3) True service office }\end{array}$ & $\begin{array}{l}\text { 1)34 respondents } \\
\text { 2) } 40 \text { respondents } \\
\text { 3) } 27 \text { respondents }\end{array}$ & $\begin{array}{l}\text { 1) } 70.8 \\
\text { 2) } 83.3 \\
\text { 3) } 56.3\end{array}$ \\
\hline $\begin{array}{l}\text { Politics, local and } \\
\text { international news }\end{array}$ & $\begin{array}{l}\text { 1)True relations } \\
\text { 2)Community leaders } \\
\text { 3)ICTs }\end{array}$ & $\begin{array}{l}\text { 1) } 46 \text { respondents } \\
\text { 2)38 respondents } \\
\text { 3) } 36 \text { respondents }\end{array}$ & $\begin{array}{l}\text { 1) } 95.8 \\
\text { 2) } 79.2 \\
\text { 3) } 75 \\
\end{array}$ \\
\hline
\end{tabular}

The results from Table 2 clearly indicate that the respondents prefer to seek information from people and familiar places. In hindsight, this is understandably so because of the assertion of Meyer, (2003) that people living in oral cultures prefer to exchange information in ways that are familiar to them and as such people within the community are key source. This will certainly have implications in certain type of ICTs usage such as social media networks, SMS and voice calls of mobile phones commonly used for interpersonal communication then Internet, Intranet portals, blogs, etc., use for searching information. Thus, agricultural extension programmes and policies, researchers need to be cautious about the type of ICTs to be used for disseminating of agricultural information to farmers in rural areas.

\subsection{Respondent's Perception of ICTs and its Usefulness to Them}

The study also explored the perceptions and usefulness of ICTs to the farmers. As highlighted by Roman and Colle, (2003) that the relevance and sustainability of technologies among rural communities depend most of the times on what they believe it can offer them. The results are shown in Table 3 in common themes with corresponding percentages below:

Table 3. Respondent's perception of ICTS and its usefulness to them

\begin{tabular}{|l|l|l|}
\hline Perception of ICTs & Frequency & Percentage \\
\hline Using computer & 13 & 27.1 \\
\hline $\begin{array}{l}\text { Tool for sending and receiving } \\
\text { message }\end{array}$ & 9 & 18.8 \\
\hline Use of technology to communicate & 10 & 20.8 \\
\hline $\begin{array}{l}\text { Use of modern and new technology } \\
\text { to communicate }\end{array}$ & 4 & 8.3 \\
\hline Don't know & 12 & 25 \\
\hline \multicolumn{2}{|c|}{ Usefulness of ICTs to respondents } \\
\hline $\begin{array}{l}\text { Communicate with friends, family } \\
\text { and other farmers }\end{array}$ & 48 & 100 \\
\hline $\begin{array}{l}\text { For the purpose of communicating } \\
\text { with my customers }\end{array}$ & 43 & 89.6 \\
\hline Banking purposes & 13 & 27.1 \\
\hline Seeking information & 7 & 14.6 \\
\hline
\end{tabular}

The most obvious result in Table 3 is that the respondents (100\%) see the usefulness of ICTs basically in terms of social interactions. 


\subsection{Type and Pattern of ICTs Usage to access/seek Agricultural Information Needs Regularly}

The study sought to determine the most ICTs tool to acquire agricultural information needs regularly. Table 4 gives the results.

Table 4. Type and pattern of ICTs to access/seek agricultural information needs

\begin{tabular}{|l|l|l|}
\hline Type of ICTs & Frequency & Percentage \\
\hline $\begin{array}{l}\text { Mobile phone (mostly as } \\
\text { medium to ask information from } \\
\text { other farmers) }\end{array}$ & 48 & 100 \\
\hline $\begin{array}{l}\text { Television (To watch agricultural } \\
\text { programs) }\end{array}$ & 9 & 18.8 \\
\hline $\begin{array}{l}\text { Radio (To listen to agricultural } \\
\text { programs) }\end{array}$ & 28 & 58.3 \\
\hline $\begin{array}{l}\text { Newspaper (To read about } \\
\text { agricultural news) }\end{array}$ & 3 & 6.3 \\
\hline $\begin{array}{l}\text { Internet as ICT tool (To search } \\
\text { agricultural information) }\end{array}$ & 5 & 10.4 \\
\hline All of the above & 2 & 4.2 \\
\hline
\end{tabular}

According to the results in Table 4 the regularly used ICT tool was mobile phone (100\%) followed by radio $(58.3 \%)$, TV $(18.8 \%)$, internet $(10.4 \%)$ and newspaper $(6.3 \%)$. The findings of the study confirm the findings of Chilimo (2008) and other past studies. The findings also affirm what Okon (2015) said, that in studying ICTs use in everyday it is critical for one to understand the social networks of people within the community been study way of exchange of information because it does play a key role in how and type of technology that will be used. Therefore it is imperative for developmental agencies task with facilitating rural development agenda when integrating and using ICTs as a tool to reach rural people needs to be cautious of this as well.

\section{CONCLUSION AND RECOMMENDATION}

According to Diekmann et al., (2009) having information on how farmers as well as medium use to search information is critical for extension educators, agricultural professionals, information specialists and marketers to be able to create effective strategies for disseminating information to the farmers.

The study set out to examine the usage of ICTs among small scale farmers in Eastern Cape Province South Africa. The findings of the study are as follows: majority of the farmers (50\%) were above 55 years. If there were more youthful farmers the expectation would have been a relatively more usage of ICTs for the purpose of seeking information as most research studies have demonstrated that the older generation is unfamiliar with recent advances in Internet for seeking information. According to Obinne, (1991) and Venkatesh (2003) education has been shown to be a factor in the adoption of high yielding modern farm practices as well as the adoption and usage of technology. Thus, the low educational levels among the farmers certainly have influence on the type and usage of ICTs to seek information and the source of seeking agricultural information. Again, the finding of the pattern of using human sources and the type of ICTs used in seeking agricultural information will certainly not fully support the achievable sustainable rural developmental goals rather it will hinder the farmers from accessing vital information put on other recent advances in Internet and ICTs for dissemination of information. Hence, the hypothesis of the study cannot be accepted.

As proposed by Hargittai and DiMaggio (2001) that meaningful ICTs usage will only be realized if it fulfills a real purpose for the user and if there is no reason for the user, technology will be quickly discarded as not important. The study recommends programmes be develop to educate rural small scale farmers about the importance and benefits that they will derived from using ICTs to support their farming activities in the information age. There is a need to do an in-depth research about e-skills of the farmers and other factors that may be causing hindrance to the usage of other recent advances of Internet and ICTs for seeking information. 


\section{REFERENCES}

Ali, L., and Avdic, A. (2015). A frame-work for ICT-based knowledge sharing in sustainable rural development: the case of Gilgit-Baltistan, Pakistan. Electronic Journal of Knowledge Management, Vol.13, No.2, pp. 103 -116.

Anyan,F. Y., and Frempong, G. (2018). An Investigation into Barriers that Hinder the Effective Use of ICT in Farming by Small Scale Farmers in Asuogyaman District, Ghana. International Journal of Humanities Social Sciences and Education (IJHSSE), vol 5, no. 1, pp. 23-32.

Bless, C., Higson-Smith, C., and Kagee, A. (2007). Fundamentals of social research methods: An African perspective. $3^{\text {rd }}$ ed. Kenwyn:Juta.

Bruckmeier, K., and Tovey, H. (2008). Knowledge in sustainable rural development: From forms of knowledge to knowledge processes. European Society for Rural Sociology, Vol. 48, pp. 313-329.

Castells, M. (2000). The information age:Economy, society and culture. Oxford: Blackwell.

Chatterjee, D., Grewal , R. and Sambamurthy, V. (2002).Shaping up for e-commerce: Institutional enablers of the organizational assimilation of web technologies. MIS Quarterly, Vol. 26, No. 2, pp. 65-89.

Chavula, H. K. (2013). The role of ICT in agricultural production in Africa, journal of development and agricultural economics, Vol. 6, No. 7, pp. 279-289.

Chambers, R., and Conway, G. (1991). Sustainable rural livelihoods: practical concepts for the $21^{\text {st }}$ century. IDS Discussion paper. No. 296, pp. 1-33.

Chilimo, W. L., (2008). Information and communication technologies and sustainable livelihoods: a case of selected rural areas of Tanzania.Unpublished $\mathrm{PhD}$ Thesis, University of KwaZulu-Natal, Pietermaritzburg.

Cullen, R. (2001). Addressing the digital divide. Online Information Review, Vol. 25, No. 5, pp. 311-320.

Friedman, T. (2006). The World is flat: The globalized world in the twenty-first century. London: Penguin Books.

Diekmann, F., Loibl, C. \& Batte, M. T. (2009). The Economics of Agricultural Information: Factors Affecting Commercial Farmers' Information Strategies in Ohio. Review of Agricultural Economics, Vol. 31, No.4, pp. 853-872.

Goldstuck, A. (2012). Internet Access in South Africa 2012. World Wide Worx.

Hargittai, E., and DiMaggio, P. (2001). From the "digital divide" to "digital inequality": Studying internet use as penetration increases. Princeton, NJ: Center for Arts and Cultural Policy Studies, Woodrow Wilson School, Princeton University.

Harris, R.M., and Dewdney, P. (1994). Barriers to information; How formal help system fail battered women. Westport, CT: Greenwood Press.

Hughes, G. C. (1991). The information age. Information Development, Vol. 7, No. 2, pp.72-74.

Jacobs, S.J. and Herselman, M. E. (2006). Information access for development: A case study at a rural community center in South Africa. Issues in Informing Science and Technology, Vol. 3, pp.295-306.

Legris, P., Ingram, J., and Collerette, P. (2003). Why do people use information technology? A critical review of the technology acceptance model. Information and Management, Vol. 40, No. 3, pp. 191-204.

James, J. (2010). Mechanisms of access to the Internet in rural areas of developing countries. Telematics and Informatices, Vol. 27, No. 4, pp. 370-376.

Job N. N., Fatima. A. A., and Halima, S. (2013). Use of ICT in Securing Marketing Information among Small Scale Farmers in Niger State, Nigeria. International Journal of Trade, Economics and Finance, Vol. 4, No. 2.

Kituyi-Kwake, A. and Adigun, M. O. (2008). Analyzing ICTS use and access amongst rural women in Kenya, International Journal of Education and Development using Information and Communication Technology, 4 (4), 127-147.

Maepa, M. E. (2000). Information needs and information seeking patterns of rural villagers in the Northern Province. Unpublished Thesis, RAU, Johannesburg.

Meyer, H. W. J.(2003). Information use in rural development. The New Review of Information Behaviour Research, Vol. 4, pp.109-126.

Musa, P. F. Meso, P., and Mbarika, V. W.(2005). Towards sustainable adoption of technologies for human development in sub-Saharan Africa: Precursors, diagnostics, and prescriptions. Communications of the Association for Information Systems, Vol. 15, No.1, pp. 592-608.

Musa, N. S., Githeko, J. M. \& El-siddig, K. (2013). The adoption and use of ICTs by small scale farmers in Gezira State, Sudan, Research Application Summary, pp.625 - 633.

Muriithi, A. G., Bett, E. and Ogaleh, S. A. (2009). Information Technology for Agriculture and Rural Development in Africa: Experiences from Kenya. Paper presented at the Conference on International Research on Food Security, Natural Resource Management and Rural Development, Tropentag 2009, University of Hamburg, October 6-8, 2009

Nyirenda-Jere, T. (2010). Unlocking the promise of ICTs for transforming agriculture in

Africa. NEPAD e-Africa Commission, CSIR, Pretoria, South Africa. Available at: http://knowledge.cta.int/index.php/en/Dossiers/S-T-Issues-in-Perspective/ICT-fortransforming-research-foragricultural-and-rural-development/Articles/Unlocking-the-Promise-of-ICTs-for-Transforming-Agriculture-in-Africa [Accessed 17/11/2018]. 
Oladele, O. I. (2006). Multilinguality of farm broadcast and agricultural information access inNigeria. Nordic J. Afr. Studies, Vol. 15, No. 2, pp. 199-205.

Okon,U. A. (2015). ICT for Rural Community Development: Implementing the Communicative Ecology Framework in the Niger Delta Region of Nigeria. IT for Development, Vol.21, No.2, pp. 297-321

Obinne, C.P. (1991). Adoption of improved cassava production technologies by small scale farmers in Bendel State. Journal of Agriculture, Science and Technology, Vol. 1, No. 1, pp. 12-15.

Ramirez, R. (2001). A model for rural and remote information and communication technologies: A Canadian exploration. Telecommunications Policy, Vol. 25, No. 5, pp. 315-330.

Rao, S. S. (2003). Information systems in Indian rural communities. Journal of Computer Information Systems, 44(1), 48-56.

Roman, R., and Colle, R. (2003). Content creation for ICT development projects: Integrating normative approaches and community demand. Information Technology for development, 10(2), 85-94.

Simumba, D. and Koopman, M. (2011). More effective information flow between researchers, extension officers and farmers in Zambia. Learning Brief, International Institute for Communication and Development (IICD). Livelihood, Zambia, January 2011.

Venkatesh, V., Morris, M. G., Davis, G. B., \& Davis, F. D. (2003). User Acceptance of Information Technology: Toward a Unified View. MIS Quarterly, Vol. 27, No. 3, pp. 425-478.

World Bank. (2008). World Data Bank, Africa Infrastructure: National Data. Available at: http://databank.worldbank.org. [Accessed: 15/05/2018].

Wong, D. M. L. (2010). Knowledge management catalyst for sustainable development. ITSim 2010 (3), pp. 1444-1449. 